\title{
Effect of chronological age of beef steers of different maturity types on their growth and carcass characteristics when finished on natural pastures in the arid sub-tropics of South Africa
}

\author{
I. du Plessis ${ }^{1,2 \#}$ and L.C. Hoffman ${ }^{2}$ \\ ${ }^{1}$ Limpopo Province Department of Agriculture, Mara Research Station, Private Bag X2467, Makhado (Louis Trichardt) \\ 0920, South Africa \\ ${ }^{2}$ Department of Animal Science, University of Stellenbosch, Private Bag X1, Matieland 7602, South Africa
}

\begin{abstract}
In the arid sweetveld regions of South Africa producers are marketing beef steers increasingly as long weaners (ca. 12 months of age) or finishing them on the natural grazing to a ready-to-slaughter stage at between 18 and 30 months of age. Limited production norms in this regard are available since most growth and carcass studies have been conducted in the sourveld regions of the country. In this study steers from four different beef maturity types which differ in body frame size were used, viz. Simmentaler crosses (large, $>500 \mathrm{~kg}$ mature weight), Bonsmara crosses (large-medium, 450-500 kg mature weight), the Afrikaner (small-medium, 400-450 kg mature weight) and the Nguni (small, $<400 \mathrm{~kg}$ mature weight). After weaning the steers in each type were randomly allocated to three groups, viz. groups slaughtered at 18,24 or 30 months of age after raising them on natural sweetveld pasture. Live weight, cold carcass weight, carcass fat classification code and number of visible incisors were recorded. Growth rates from weaning to 24 months of age were similar for the different maturity types, though the Afrikaner steers gained significantly less than the Bonsmara crossbreds. Periods where high growth rates occurred (at 12 to 18 months of age and 24 to 30 months of age) coincided with the rainy season. Relatively low dressing percentages were noted and could be attributed to the fact that all internal organs and fat were removed at slaughtering, as well as a possible high level of gut fill. Due to genetic variation within maturity types it was not possible to predict the market readiness of a particular individual from its live weight. The carcass weights were heavier for steers slaughtered at 24 months of age than those at 18 months of age, but had a lower fat classification code. This seems to be due to the fact that these steers were slaughtered at the end of the winter period when the quality of the grazing was at its lowest. The carcasses of all maturity types had the highest fat classification codes at 30 months of age. However, the carcasses of $77.8 \%$ of the Simmentaler crossbreds were graded 1 (lean) in the fat classification. Furthermore, at 30 months of age $23.8 \%$ of all steers had more than two permanent incisors. This increases their carcass age classification, which lowers their carcass grading according to the South African grading standards, and thus their price per kg relative to the younger ages. The results of this investigation indicated that steers of all frame sizes would have to be fed additional energy to ensure that they finish with a fat classification code of at least 2 before the age of 30 months to ensure optimal financial returns.
\end{abstract}

Keywords: Growth, carcass traits, maturity type, steers, age, natural pasture, carcass classification, incisors \#Corresponding author. E-mail: iduplessis@lantic.net

\section{Introduction}

Scott (1947) classified the natural grazing in South Africa as sweet- and sourveld. He defined "sweetveld" as natural grazing which remains palatable and nutritious throughout the year, even when mature, whereas the "sourveld" provides palatable material only in the growing season. Animal growth during the winter period in sourveld regions is predominantly negative, while in the sweetveld positive animal growth can occur in winter.

Most growth and carcass related studies conducted in South Africa have been restricted to the sourveld areas (Reyneke, 1976; Van der Merwe et al., 1980; Gertenbach \& Henning, 1995a) and, due to the animal husbandry practices in these regions, this inevitably led to investigations into animal growth and/or carcass characteristics from cultivated pastures (Gertenbach et al., 1995: Le Roux et al., 1999a; b), in feedlots (Swanepoel et al., 1990; Gertenbach \& Henning, 1995b; Strydom et al., 2001;) or in feedlots where the animals received growth stimulating implants (Meaker \& Barnard, 1988). The enhancement of poor quality roughages (especially crop residues) also received attention (Brand et al., 1989; Snyman \& Joubert, 2002; 
Taute et al., 2002). However, little if any scientific research has apparently been published on the finishing of steers on natural pastures in the sub-tropical sweetveld regions of southern Africa.

Production systems where beef steers are marketed at 18 to 30 months of age rather than as weaners have been suggested to be better suited to arid environmental conditions (Coetzee, 1971). This management practice introduces more flexibility to the producer's marketing strategy, by allowing for timely control of animal numbers in relation to erratic rainfall patterns. Thus, the risk involved in farming with cattle in arid regions would be reduced. In practice, producers use different maturity types to produce meat from natural pastures. The aim of this study was to define criteria for growth and carcass characteristics for maturity types which vary in frame size at the end of the wet (at 18 and 30 months of age) and dry seasons (at 24 months of age) of the year, so that decisions can be made, based on optimal production and marketing of steers directly from natural sweet pastures.

\section{Materials and Methods}

The study was conducted from 1995 to 2001 on ca. 4387 ha on the eastern side of the Mara Research

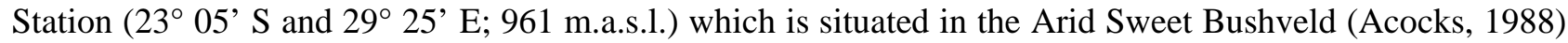
of the Limpopo Province of South Africa. The vegetation in the study area includes the woody tree species, Acacia tortilis, Commiphora pyracanthoides, Boscia albitrunca and Grewia spp. and the grass species, Eragrostis rigidior, Panicum maximum, Urochloa mosambicensis and Digitaria eriantha (Dekker et al., 2001). The long term mean rainfall is $452 \mathrm{~mm}$, but during the study period the mean annual rainfall (measured from July to June) was $498 \mathrm{~mm}$, ranging from $232 \mathrm{~mm}$ to $846 \mathrm{~mm}$, of which approximately $80 \%$ occurred from November to March. The mean daily maximum temperature ranged from $22.6^{\circ} \mathrm{C}$ in June to $30.4^{\circ} \mathrm{C}$ in January.

The Simmentaler crossbred (SX) steers were bred from cows originating from a two-way Simmentaler $\mathrm{x}$ Afrikaner crossbreeding study. Cows consisting of approximately two thirds Simmentaler were mated with a Simmentaler bull, representing large-framed maturity types. The cows of the reciprocal cross were mated to Bonsmara bulls to represent the large-medium framed maturity types (BX). Purebred Afrikaner (AF) and Nguni (NG) steers represented small-medium and small-framed maturity types, respectively. Cows were selected throughout the trial period to comply with weight criteria and early maturing Bonsmara bulls were used to ensure that differences in frame size occurred between the steers of the different maturity types.

Due to logistical constraints the different steer groups were allocated in separate, but adjacent camps for the entire study period. To reduce possible camp effects the stocking rates (ha/LSU) were balanced according to the metabolic body weight (Meissner et al., 1983) of the animals. Stocking rates were managed to ensure that they did not exceed $12 \mathrm{ha} / \mathrm{LSU}$.

Calves were born from the end of October to the middle of December. All steers were weaned simultaneously when the last steer reached 205 days of age (mean age $=237 \pm 22$ days). Castration took place during the weaning phase. Other herd management practices (e.g. dipping, vaccination) were standardised for all breeds. No supplementary feeds or licks were supplied.

Steers born during a specific calving season were randomly divided per maturity type into three groups and slaughtered at 18, 24 or 30 months of age, respectively. Steers were born from October to December and slaughtered either in May (18 and 30 months of age) or November (24 months of age). Live weights were recorded at 28 day intervals after withholding food and water for at least 12 hours. Live weights at 18, 24 and 30 months of age (548, 730 and 912 days of age, respectively) were either interpolated or extrapolated from the 28 day weighing records, depending on whether the steers were slaughtered before or after reaching the slaughtering age. Cold carcass weight was determined 24 hours post mortem and was used to calculate dressing percentage from the actual live weight. Carcass weight at a specific age was then calculated as the product of the corrected live weight and the dressing percentage. The carcasses were classified according to the official carcass classification system (Government notice no. R. 1748, 26 June 1992) as summarised in Table 1 . No fat thickness measurements were taken. The number of visible permanent incisors was also recorded.

Live weight, carcass weight, dressing percentage as well as weight gain and relative weight gains were analysed with the univariate analysis of variance of the GLM procedures (SPSS, 2002). Age at slaughter, maturity type and year of birth were included as main effects. All two-way interactions were included in the model. Actual age at slaughter was included as a covariate in all applicable cases. Significant differences between means were computed, using the Bonferoni procedure (SPSS, 2002). Frequency distributions of fat classification codes and number of visible permanent incisors for age at slaughter and maturity type were 
analysed, using the Kruskal-Wallis test (SPSS, 2002). Differences in frequency distributions were computed, using the Mann-Whitney test (SPSS, 2002).

Table 1 Summary of the age and fat classification codes used to classify carcasses (Government notice no. R. 1748, 26 June 1992)

\begin{tabular}{lllcc}
\hline $\begin{array}{l}\text { Age* } \\
\text { description }\end{array}$ & $\begin{array}{l}\text { Age } \\
\text { classification } \\
\text { code }\end{array}$ & Fat description & $\begin{array}{c}\text { Thickness of subcutaneous } \\
\text { fat layer (mm) }\end{array}$ & $\begin{array}{c}\text { Fat class } \\
\text { code }\end{array}$ \\
\cline { 2 - 4 } 0 Teeth & A & No fat & 0 & 0 \\
1-2 Teeth & AB & Very lean & $<1$ & 1 \\
3-6 Teeth & B & Lean & $1-3$ & 2 \\
$>6$ Teeth & C & Lean & $>3-5$ & 3 \\
& & Fat & $>5-7$ & 4 \\
& & Over fat & $>7-10$ & 5 \\
\hline
\end{tabular}

* Number of permanent incisors

\section{Results and Discussion}

The periods from 7 to 12 months of age and from 18 to 24 months of age coincided with the winter season, while the periods from 12 to 18 months of age and from 24 to 30 months of age coincided with the summer season. During the winter seasons the growth rates of all steers were lower $(\mathrm{P}<0.05)$ than during the summer seasons (Figure 1). This is mainly due to high quality, easily digestible grazing available during summer, and the low quality and digestibility of the vegetation during winter (Relling et al., 2001).

It is noticeable that steers of the different maturity types maintained similar growth rates up to 24 months of age (Figure 1). Weights used in compiling Figure 1 were not corrected for age. Although there were significant $(\mathrm{P}<0.05)$ differences (Table 2$)$ in the mean live weight gain of the respective maturity types from weaning to 12 months of age and from 18 to 24 months of age, these differences were small in terms of the absolute growth rates and from 12 to 18 months of age growth rates were similar for all maturity types. The mean live weight gain from weaning to 24 months was similar for all breeds except for the BX steers $(162.6 \mathrm{~kg})$ that gained significantly $(\mathrm{P}<0.05)$ more than the AF steers $(139.6 \mathrm{~kg})$. Results reported by Cianzio et al. (1982) support these findings. They reported that the growth rates of large and small framed steers on a growing-finishing diet were similar from 11 to 19 months of age. The similar growth rates of the large framed SX, BX and the small framed NG steers in the present study imply that the growth rate of immature steers under the grazing conditions in this study was limited to a maximum threshold. This viewpoint is supported by Crouse et al. (1985) who reported that the energy intake (MJ ME/d) of Simmentaler cattle was higher $(\mathrm{P}<0.01)$ than that of Angus cattle on a high-energy diet, but similar on a low-energy diet. In contrast, Prior et al. (1977) suggested that on low-energy diets energy intake may be limited by bulk fill in smaller framed steers, but not in large-framed steers. The low energy diets in their study contained between 45 and 52\% maize. On an all forage diet, as in the present study, it can be assumed that bulk fill could have limited energy intake in all breeds to the extent that only minor differences in growth rates between maturity types of different frame sizes could be manifested. Nguni and AF steers had lower $(\mathrm{P}<0.05)$ growth rates from 24 to 30 months of age than the SX and BX steers (Table 2). Similarly, O'Mary et al. (1979) reported that the growth rate of small-framed Angus steers slowed down when they started to finish after 120 days of a 150 day feeding period, while the large-framed Charolais steers maintained a high growth rate throughout the feeding period. This could be due to the fact that especially NG steers had reached maturity in terms of live weight gain and were finishing off. Fortin et al. (1981) observed that differences between breeds in terms of carcass composition did not appear to be the result of different growth rates for the various tissues, but were rather due to differences in the onset of rapid fattening, with small-framed, early maturing maturity types starting to deposit fat at an earlier age than large-framed, late maturing types.

If growth rates are expressed relative to either live weight or expected mature weight (Table 2), NG and $\mathrm{BX}$ steers maintained higher $(\mathrm{P}<0.05)$ relative growth rates from seven to 12 months of age than the AF steers, while NG steers maintained significantly higher relative growth rates than the SX, BX and AF steers 
from 18 to 24 months of age. From 18 to 24 months of age the AF steers maintained the lowest relative growth rate $(\mathrm{P}<0.05)$. Both periods coincide with the dry winter periods when the nutritional status of the natural pasture is low. From 12 to 18 months (summer period) the NG and AF steers had higher $(\mathrm{P}<0.05)$ relative growth rates than the SX and BX steers. Although NG steers had the lowest $(\mathrm{P}<0.05)$ relative growth rate between 24 and 30 months of age, their relative growth rates were similar to those of the other maturity types during the other growing periods.

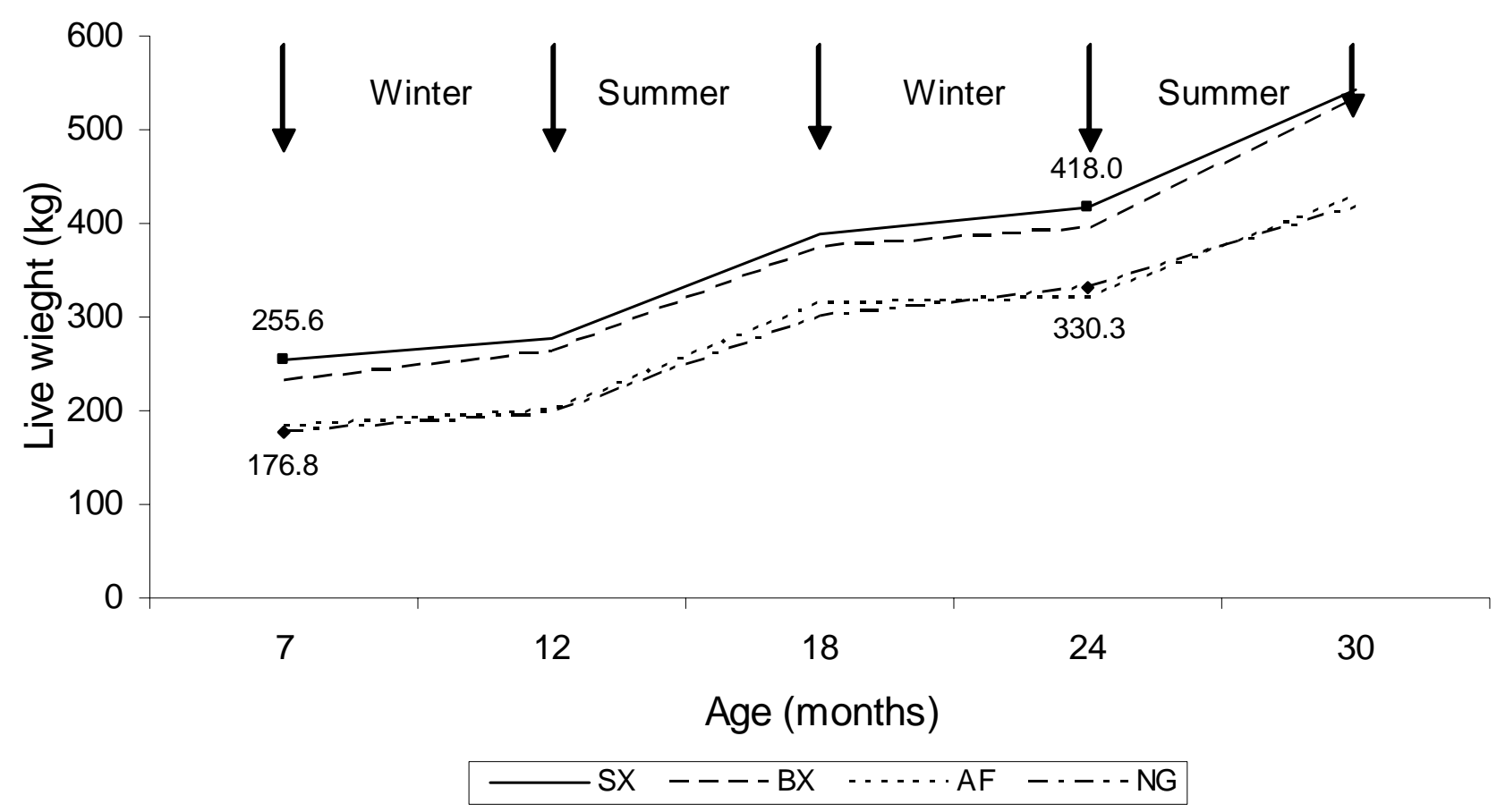

Figure 1 Postweaning growth of Simmentaler crossbred (SX), Bonsmara crossbred (BX), Afrikaner (AF) and Nguni (NG) steers

Across maturity types absolute growth rates and growth rates relative to expected mature weight followed the same pattern, being lower $(\mathrm{P}<0.001)$ during the winter periods than during the summer periods. Live weight gain relative to live weight differed $(\mathrm{P}<0.001)$ between all growing periods. It was lowest between 18 and 24 months of age, most probably because the quality of the grazing was lower than during the summer grazing periods and that maintenance requirements are higher than for weaning, allowing very little nutrients for growth.

When compared on a constant age basis, various authors reported that large-framed breeds grew faster than small-framed breeds (Smith et al., 1976; Koch et al., 1979; Crouse et al., 1985). These comparisons, however, considered the whole growing period and did not differentiate between the high growth rate growing phases and the slower-growth-rate finishing phases of small-framed cattle. These reports obscured the possibility that small-framed breeds may grow at similar rates as large-frame breeds during the highgrowth-rate phase before the onset of fattening starts the slow-growth-rate finishing phase (O'Mary et al., 1979).

Live weight, carcass weight and dressing percentage (Table 3) increased with increasing age (18 months $<24$ months $<30$ months; $\mathrm{P}<0.01$ ). For all three traits the maturity type $\mathrm{x}$ year of birth interaction was significant $(\mathrm{P}<0.05)$, while for live weight and carcass weight the age at slaughter $\mathrm{x}$ maturity type interaction was significant $(\mathrm{P}<0.01)$. For dressing percentage the age at slaughter $\mathrm{x}$ the year of birth interaction was significant $(\mathrm{P}<0.001)$. These interactions were only significant for the treatment groups slaughtered at 30 months of age. Mainly all interactions involving maturity type were due to the AF steers performing contrary to expectations.

Differences in live weight (\% gain above 18 month weight in parenthesis) for steers slaughtered at 18 and 24 months of age (dry winter season) were: $52.9 \mathrm{~kg}$ (14.4\%), $5.9 \mathrm{~kg}$ (1.5\%), $9.1 \mathrm{~kg}$ (2.8\%) and $58.1 \mathrm{~kg}$ 
(20.2\%) for SX, BX, AF and NG steers, respectively. In contrast, the differences in live weight (\% gain above 24 month weight in parenthesis) for steers slaughtered at 24 and 30 months of age (wet summer season) were higher $(\mathrm{P}<0.01)$, and were $155.0 \mathrm{~kg}$ (36.9\%), $154.4 \mathrm{~kg}(39.0 \%), 129.5 \mathrm{~kg}(39.1 \%)$ and $92.8 \mathrm{~kg}$ (26.7\%) for the SX, BX, AF and NG steers, respectively. Although no conclusive evidence exists, based on the findings of Dikeman et al. (1985a; b) and Harris et al. (1997) it can be assumed that at least a portion of the rapid increase in live weight that occurred from December to May during the rainy season, when abundant food was available, could be ascribed to compensatory growth.

Table 2 Live weight gain as well as live weight gain relative to live weight and expected mature weight ( \pm s.e.) for Simmentaler crossbred, Bonsmara crossbred, Afrikaner and Nguni steers

\begin{tabular}{|c|c|c|c|c|c|}
\hline \multirow[b]{2}{*}{ Frame size type } & \multirow{2}{*}{$\begin{array}{l}\text { Expected } \\
\text { mature } \\
\text { weight }(\mathrm{kg})\end{array}$} & \multicolumn{4}{|c|}{ Live weight gain (kg) } \\
\hline & & $\begin{array}{l}7 \text { to } 12 \text { months } \\
\text { (winter) }\end{array}$ & $\begin{array}{c}12 \text { to } 18 \text { months } \\
\text { (summer) }\end{array}$ & $\begin{array}{l}18 \text { to } 24 \text { months } \\
\text { (winter) }\end{array}$ & $\begin{array}{l}24 \text { to } 30 \text { months } \\
\text { (summer) }\end{array}$ \\
\hline Simmentaler cross & & $21.8^{\mathrm{abc}} \pm 2.5$ & $112.3 \pm 3.9$ & $21.5^{\mathrm{a}} \pm 2.6$ & $128.1^{\mathrm{a}} \pm 9.6$ \\
\hline Bonsmara cross & & $30.6^{\mathrm{b}} \pm 3.1$ & $110.9 \pm 3.6$ & $21.9^{\mathrm{a}} \pm 4.5$ & $139.3^{\mathrm{a}} \pm 5.5$ \\
\hline Afrikaner & & $15.8^{\mathrm{c}} \pm 2.4$ & $113.9 \pm 2.0$ & $6.3^{\mathrm{b}} \pm 3.5$ & $114.4^{\mathrm{ab}} \pm 6.2$ \\
\hline Nguni & & $21.1^{\mathrm{ac}} \pm 2.6$ & $102.3 \pm 3.3$ & $32.0^{\mathrm{a}} \pm 3.2$ & $94.2^{\mathrm{b}} \pm 5.8$ \\
\hline Mean & & $23.4^{\mathrm{d}} \pm 1.5$ & $109.7^{\mathrm{e}} \pm 1.8$ & $20.9^{\mathrm{d}} \pm 2.0$ & $120.3^{\mathrm{e}} \pm 4.1$ \\
\hline & & \multicolumn{4}{|c|}{ Live weight gain relative to live weight } \\
\hline Simmentaler cross & & $0.0893 \pm 0.0109$ & $0.4105^{\mathrm{a}} \pm 0.0164$ & $0.0562^{\mathrm{a}} \pm 0.0072$ & $0.3093 \pm 0.0254$ \\
\hline Bonsmara cross & & $0.1391 \pm 0.0154$ & $0.4305^{\mathrm{a}} \pm 0.0190$ & $0.0594^{\mathrm{a}} \pm 0.0128$ & $0.3579 \pm 0.0179$ \\
\hline Afrikaner & & $0.0906 \pm 0.0145$ & $0.5805^{\mathrm{b}} \pm 0.0194$ & $0.0195^{\mathrm{a}} \pm 0.0110$ & $0.3424 \pm 0.0350$ \\
\hline Nguni & & $0.1266 \pm 0.0155$ & $0.5253^{\mathrm{b}} \pm 0.0200$ & $0.1096^{\mathrm{b}} \pm 0.0117$ & $0.2920 \pm 0.0176$ \\
\hline Mean & & $0.1150^{\mathrm{d}} \pm 0.0079$ & $0.4791^{\mathrm{e}} \pm .00109$ & $0.0622^{\mathrm{f}} \pm 0.0062$ & $0.3268^{\mathrm{g}} \pm 0.0124$ \\
\hline & & \multicolumn{4}{|c|}{ Live weight gain relative to expected mature weight } \\
\hline Simmentaler cross & 575 & $0.0402^{\mathrm{abc}} \pm 0.0046$ & $0.2069^{\mathrm{a}} \pm 0.0044$ & $0.0396^{\mathrm{a}} \pm 0.0048$ & $0.2359 \pm 0.0178$ \\
\hline Bonsmara cross & 550 & $0.0575^{\mathrm{b}} \pm 0.0058$ & $0.2082^{\mathrm{a}} \pm 0.0068$ & $0.0412^{\mathrm{a}} \pm 0.0084$ & $0.2615 \pm 0.0103$ \\
\hline Afrikaner & 460 & $0.0367^{c} \pm 0.0056$ & $0.2638^{\mathrm{b}} \pm 0.0047$ & $0.0147^{\mathrm{a}} \pm 0.0082$ & $0.2668 \pm 0.0145$ \\
\hline Nguni & 440 & $0.0506^{\mathrm{abc}} \pm 0.0062$ & $0.2449^{\mathrm{b}} \pm 0.0079$ & $0.0765^{\mathrm{b}} \pm 0.0077$ & $0.2256 \pm 0.0138$ \\
\hline Total & & $0.0458^{\mathrm{d}} \pm 0.0029$ & $0.217^{\mathrm{e}} \pm 0.0037$ & $0.0423^{\mathrm{d}} \pm 0.0040$ & $0.2348^{\mathrm{e}} \pm 0.0068$ \\
\hline
\end{tabular}

a,b,c, Column means within weight gain groups with different superscripts differ $(\mathrm{P}<0.05)$

${ }^{\mathrm{d}, \mathrm{e}, \mathrm{f}, \mathrm{g}}$ Row means within totals with different superscripts differ $(\mathrm{P}<0.001)$

The gain in carcass weight (\% gain above 18 month weight in parenthesis) for steers slaughtered at 18 and 24 months of age was $36.6 \mathrm{~kg}(21.0 \%), 6.4 \mathrm{~kg}(3.4 \%), 5.7 \mathrm{~kg}(3.8 \%)$ and $33.5 \mathrm{~kg}(23.6 \%)$ for the SX, $\mathrm{BX}, \mathrm{AF}$ and NG steers, respectively, while higher $(\mathrm{P}<0.01)$ carcass weight gains were realized from 24 to 30 months of age (\% gain above 24 month weight in parenthesis) and were $86.7 \mathrm{~kg}(41.1 \%), 88.0 \mathrm{~kg}$ (44.7\%), $68.8 \mathrm{~kg}(43.9 \%)$ and $55.0 \mathrm{~kg}$ (31.4\%) for SX, BX, AF and NG steers, respectively.

Dressing percentages (Table 3) in this study were lower than the 60\% (Koch et al., 1976; May et al., 1992; Wheeler, et al., 1996; Pringle et al., 1997) or the 57\% (Strydom et al., 2001) generally reported for grain-fed cattle. It is within expectations that the dressing percentage of the animals in this study will be lower than that of grain-fed cattle. It was, however, not expected that the dressing percentage would be less than that reported from other studies on forage-fed cattle. Schroeder et al. (1980) and Camfield et al. (1999) reported dressing percentages ranging from $53.4 \%$ to $58.0 \%$ and $55.3 \%$ to $56.9 \%$, respectively, for foragefinished cattle. Possible reasons could be the low degree of finish of the carcasses (low carcass fat classifications) especially at 18 and 24 months of age, and that all internal fat and organs (including kidneys and pelvic fat) were removed during slaughter and/or the phenomenon that the body fill in grass-fed cattle is higher than in grain-fed cattle (Young \& Kauffman, 1978; Bidner et al., 1986; Bennett et al., 1995). Furthermore, cattle in the USA are slaughtered at a higher fat content in the carcass, resulting in comparatively higher dressing percentages.

Although AF steers tended to have a lower dressing percentage at all ages than the other groups, it was only significant $(\mathrm{P}<0.01)$ at 30 months of age (Table 3$)$. Dressing percentage increased $(\mathrm{P}<0.01)$ with increasing age. An increase in dressing percentage with increasing age was also reported by Moody et al. (1970). 
No breed differences in terms of mean live and carcass weights were found between different years of birth. Breed differences, however, occurred at 24 and 30 months of age for dressing percentage. It is not clear why, but especially steers born in 1996 had a significantly lower dressing percentage at 24 months of age than steers born in 1995, 1997 and 1998 and slaughtered at 24 months of age. The other cases may be due to natural genetic and environmental variations that occurred.

Table 3 Average live weight, carcass weight and dressing percentage ( \pm s.e.) of Simmentaler crossbred, Bonsmara crossbred, Afrikaner and Nguni steers slaughtered at 18, 24 and 30 months of age

\begin{tabular}{|c|c|c|c|c|c|c|}
\hline $\begin{array}{l}\text { Age at } \\
\text { slaughter } \\
\text { (months) }\end{array}$ & $\begin{array}{l}\text { Frame size type / } \\
\text { Year of birth }\end{array}$ & $\mathrm{n}$ & $\begin{array}{l}\text { Age at } \\
\text { slaughter } \\
\text { (days) }\end{array}$ & Live weight (kg) & $\begin{array}{c}\text { Cold Carcass } \\
\text { weight }(\mathrm{kg})\end{array}$ & Dressing \% \\
\hline \multirow[t]{9}{*}{18} & Simmentaler cross & 9 & 536 & $367.1^{\mathrm{ab}} \pm 11.6$ & $174.4^{\mathrm{a}} \pm 7.6$ & $47.42 \pm 0.90$ \\
\hline & Bonsmara cross & 9 & 544 & $387.1^{\mathrm{a}} \pm 8.8$ & $184.6^{\mathrm{ab}} \pm 7.2$ & $47.66 \pm 1.47$ \\
\hline & Afrikaner & 8 & 537 & $321.8^{b c} \pm 8.6$ & $150.9^{\mathrm{ac}} \pm 4.8$ & $46.87 \pm 0.74$ \\
\hline & Nguni & 10 & 559 & $289.8^{\mathrm{C}} \pm 14.5$ & $141.7^{\mathrm{ac}} \pm 8.0$ & $48.91 \pm 1.70$ \\
\hline & Mean & 36 & 544 & $340.6^{\mathrm{h}} \pm 8.6$ & $162.6^{\mathrm{h}} \pm 4.5$ & $47.77^{\mathrm{h}} \pm 0.65$ \\
\hline & 1995 & 1 & 629 & 349.4 & 158.9 & 45.48 \\
\hline & 1996 & 14 & 519 & $352.4 \pm 15.8$ & $166.2 \pm 4.2$ & $47.04 \pm 1.06$ \\
\hline & 1997 & 16 & 536 & $333.3 \pm 12.7$ & $161.6 \pm 6.3$ & $48.60 \pm 0.88$ \\
\hline & 1998 & 5 & 626 & $329.1 \pm 15.8$ & $156.8 \pm 9.7$ & $47.64 \pm 1.80$ \\
\hline \multirow[t]{9}{*}{24} & Simmentaler cross & 13 & 745 & $419.5^{\mathrm{a}} \pm 14.4$ & $211.0^{\mathrm{a}} \pm 10.6$ & $50.17 \pm 1.43$ \\
\hline & Bonsmara cross & 17 & 726 & $395.3^{\mathrm{a}} \pm 17.1$ & $196.7^{\mathrm{a}} \pm 8.3$ & $49.96 \pm 1.26$ \\
\hline & Afrikaner & 9 & 726 & $330.9^{b} \pm 12.5$ & $156.6^{\mathrm{b}} \pm 3.5$ & $47.63 \pm 1.25$ \\
\hline & Nguni & 12 & 721 & $347.9^{\mathrm{b}} \pm 10.0$ & $175.2^{\mathrm{b}} \pm 5.7$ & $50.46 \pm 1.31$ \\
\hline & Mean & 51 & 729 & $378.9^{\mathrm{h}} \pm 8.7$ & $188.2^{\mathrm{i}} \pm 4.9$ & $49.72^{\mathrm{h}} \pm 0.67$ \\
\hline & 1995 & 9 & 707 & $382.6 \pm 13.5$ & $196.0 \pm 8.4$ & $51.19^{\mathrm{e}} \pm 3.11$ \\
\hline & 1996 & 16 & 721 & $381.1 \pm 15.2$ & $172.1 \pm 6.8$ & $45.22^{f} \pm 0.54$ \\
\hline & 1997 & 15 & 757 & $355.0 \pm 16.1$ & $194.8 \pm 11.1$ & $54.56^{\mathrm{g}} \pm 0.97$ \\
\hline & 1998 & 11 & 722 & $405.6 \pm 22.4$ & $196.1 \pm 10.6$ & $48.47^{\mathrm{e}} \pm 0.82$ \\
\hline \multirow[t]{9}{*}{30} & Simmentaler cross & 16 & 899 & $575.0^{\mathrm{a}} \pm 14.4$ & $297.7^{\mathrm{a}} \pm 8.65$ & $51.74^{\mathrm{a}} \pm 0.58$ \\
\hline & Bonsmara cross & 17 & 907 & $549.7^{\mathrm{b}} \pm 14.9$ & $284.9^{b} \pm 7.7$ & $51.85^{\mathrm{a}} \pm 0.30$ \\
\hline & Afrikaner & 13 & 880 & $460.4^{c} \pm 12.3$ & $225.4^{\mathrm{c}} \pm 6.0$ & $48.99^{\mathrm{b}} \pm 0.51$ \\
\hline & Nguni & 17 & 899 & $440.7^{\mathrm{d}} \pm 8.0$ & $230.2^{c} \pm 4.6$ & $52.20^{\mathrm{a}} \pm 0.37$ \\
\hline & Mean & 63 & 897 & $508.3^{\mathrm{i}} \pm 9.6$ & $261.1^{\mathrm{j}} \pm 5.3$ & $51.33^{\mathrm{i}} \pm 0.27$ \\
\hline & 1995 & 16 & 885 & $492.1 \pm 21.3$ & $249.6 \pm 11.5$ & $50.69^{\mathrm{e}} \pm 0.53$ \\
\hline & 1996 & 18 & 875 & $525.6 \pm 20.9$ & $274.2 \pm 11.3$ & $52.12^{f} \pm 0.39$ \\
\hline & 1997 & 18 & 914 & $497.2 \pm 14.1$ & $259.5 \pm 8.0$ & $52.15^{\mathrm{f}} \pm 0.43$ \\
\hline & 1998 & 11 & 921 & $521.5 \pm 19.4$ & $259.1 \pm 11.1$ & $49.62^{g} \pm 0.62$ \\
\hline Total & & 150 & & $424 \pm 8.1$ & $212.7 \pm 4.6$ & $49.93 \pm 0.32$ \\
\hline
\end{tabular}

Although the live and carcass weights were higher $(\mathrm{P}<0.01)$ at 24 months of age than at 18 months of age, steers had less $(\mathrm{P}<0.01)$ fat on the carcasses at 24 months of age (Table 4). This is expected since the steers reached the age of 24 months just after the winter dry season and the ages of 18 and 30 months just after the rainy summer season. Carcasses that received a 2 fat classification code were deemed to be finished to a marketable degree. The largest portion of the steers reached a marketable finishing standard at 30 months of age, except for the SX steers that were still not finished, according to the current carcass classification standards. The majority of SX carcasses received 1 fat classification codes $(<1 \mathrm{~mm}$ 
subcutaneous fat) at 30 months of age, but the fat covered mainly the dorsal areas of the carcasses and was not distributed down to the ventral parts and was also very unevenly distributed. The same fat classification code and the fat covering of the BX, AF and NG carcasses were more continuous and were distributed down to the ventral parts of the carcasses. According to Camfield et al. (1999) the differences in measures of carcass fatness are greater and more attainable in steers developed in feedlots than in steers developed on pastures. In feedlots nutrients are supplied in excess of what is needed for maximal bone and muscle growth and the surplus nutrients are used in the formation of fatty tissue. Although it seems as if the supply of nutrients might have been enough to allow for the accumulation of fatty tissue in BX, AF and NG steers, the excess supply might not have been sufficient to expressed differences in rates of fatty tissue accumulation between breeds. Hence, no significant differences in the distribution of the BX, AF and NG carcasses receiving 1 and 2 fat classification codes were observed for all age groups. Also, the low numbers observed in this study, may have played a role in this observation.

Table 4 The frequency distribution of carcasses of Simmentaler crossbred, Bonsmara crossbred, Afrikaner and Nguni steers within the respective fat classification codes at 18, 24 and 30 months of age

\begin{tabular}{|c|c|c|c|c|c|}
\hline \multirow{2}{*}{$\begin{array}{c}\text { Age at } \\
\text { slaughter } \\
\text { (months) }\end{array}$} & \multirow{2}{*}{ Frame size type } & \multicolumn{4}{|c|}{ Number of carcasses in each fat classification code } \\
\hline & & Fat code 0 & Fat code 1 & Fat code 2 & Fat code 3 \\
\hline \multirow[t]{5}{*}{18} & Simmentaler cross $^{\mathrm{C}}$ & 7 & 1 & 1 & \\
\hline & Bonsmara cross ${ }^{\mathrm{d}}$ & 1 & 4 & 4 & \\
\hline & Afrikaner $^{\mathrm{d}}$ & & 3 & 5 & \\
\hline & Nguni $^{\mathrm{d}}$ & & 5 & 5 & \\
\hline & Total $^{\mathrm{a}}$ & 8 & 13 & 15 & \\
\hline \multirow[t]{5}{*}{24} & Simmentaler cross ${ }^{\mathrm{c}}$ & 9 & 4 & & \\
\hline & Bonsmara cross ${ }^{\mathrm{d}}$ & 3 & 9 & 5 & \\
\hline & Afrikaner $^{\mathrm{d}}$ & & 9 & & \\
\hline & Nguni $^{\mathrm{d}}$ & & 8 & 4 & \\
\hline & Total $^{\mathrm{a}}$ & 12 & 30 & 9 & \\
\hline \multirow[t]{5}{*}{30} & Simmentaler cross ${ }^{\mathrm{C}}$ & 3 & 12 & 1 & \\
\hline & Bonsmara cross ${ }^{\mathrm{d}}$ & & & 13 & 4 \\
\hline & Afrikaner $^{\text {de }}$ & & 2 & 8 & 3 \\
\hline & Nguni $^{\mathrm{e}}$ & & 1 & 16 & \\
\hline & Total $^{\text {b }}$ & 3 & 15 & 38 & 7 \\
\hline \multirow[t]{5}{*}{ Total } & Simmentaler cross ${ }^{\mathrm{C}}$ & 19 & 17 & 2 & \\
\hline & Bonsmara cross ${ }^{\mathrm{d}}$ & 4 & 13 & 22 & 4 \\
\hline & Afrikaner $^{\mathrm{d}}$ & & 14 & 13 & 3 \\
\hline & Nguni $^{\mathrm{d}}$ & & 14 & 25 & \\
\hline & Total & 23 & 58 & 62 & 7 \\
\hline
\end{tabular}

a,b,c Total for slaughter age groups with different superscripts differ $(\mathrm{P}<0.01)$

${ }^{\mathrm{d}, \mathrm{e}}$ Breeds within age groups with different superscripts differ $(\mathrm{P}<0.05)$

Carcass data (Tables 3 and 5) and fat classification results (Table 4) are in agreement with the results of Camfield et al. $(1994 ; 1997)$ who found that at the same chronological age, large framed, slower maturing steers have heavier carcasses $(\mathrm{P}<0.01)$ but are less finished $(\mathrm{P}<0.05)$ than medium framed, faster maturing steers. Tatum et al. (1990) also reported that Piedmontese sired steers had the least fat thickness compared to Gelbvieh and Red Angus sired steers, when slaughtered at the same chronological age. Schaake et al. (1993) reported that although the fat thickness of steers on spring fescue-clover, summer pasture (640 days of age) and steers fed a feedlot diet for 45 days after the same grazing treatment (685 days of age), did not differ statistically, feedlot steers tended to have a greater fat thickness $(P=0.07)$ than pasture raised steers. The fat thickness of steers raised on pastures until 640 days of age and then finished in a feedlot for 75 days was greater than for pastures raised steers (640 days) (Schaake et al., 1993). The frequency distributions of carcasses in fat classification code classes were similar at 18 and 24 months of age, but at 30 months of age 
more $(\mathrm{P}<0.01)$ carcasses achieved higher fat classification codes. In order to ensure better fat classification codes, it would be beneficial to feedlot-feed or supply a supplement to the natural pasture for all maturity type steers to be slaughtered at 18 or 24 months of age for a short period of time. A period of 45 to 75 days should be sufficient.

Table 5 Average weights ( \pm s.d.) and weight ranges for Simmentaler crossbred, Bonsmara crossbred, Afrikaner and Nguni steers slaughtered at 18, 24 and 30 months of age

\begin{tabular}{|c|c|c|c|c|c|c|}
\hline \multirow{2}{*}{$\begin{array}{c}\text { Age at } \\
\text { slaughter } \\
\text { (months) }\end{array}$} & \multirow[b]{2}{*}{ Frame size type } & & \multicolumn{4}{|c|}{ Live weight (kg) per fat code } \\
\hline & & & Fat code 0 & Fat code 1 & Fat code 2 & Fat code 3 \\
\hline & Simmentaler cross & $\mathrm{n}$ & 7 & 1 & 1 & \\
\hline & & Mean (kg) & $356.9 \pm 47.2$ & 336 & 350 & \\
\hline & & Range (kg) & $284-420$ & & & \\
\hline & Bonsmara cross & $\mathrm{n}$ & 1 & 4 & 4 & \\
\hline & & Mean (kg) & 408 & $392 \pm 33.8$ & $361 \pm 31.9$ & \\
\hline & & Range (kg) & & $362-434$ & $328-404$ & \\
\hline & Afrikaner & $\mathrm{n}$ & & 3 & 5 & \\
\hline & & Mean (kg) & & $294 \pm 28.4$ & $300 \pm 16.6$ & \\
\hline & & Range (kg) & & $272-326$ & $278-316$ & \\
\hline & Nguni & $\mathrm{n}$ & & 5 & 5 & \\
\hline & & Mean (kg) & & $316 \pm 37.2$ & $277 \pm 43.6$ & \\
\hline & & Range (kg) & & $262-366$ & $222-332$ & \\
\hline \multirow[t]{12}{*}{24} & Simmentaler cross & $\mathrm{n}$ & 9 & 4 & & \\
\hline & & Mean (kg) & $417 \pm 44.0$ & $400 \pm 49.8$ & & \\
\hline & & Range (kg) & $372-510$ & $330-466$ & & \\
\hline & Bonsmara cross & $\mathrm{n}$ & 3 & 9 & 5 & \\
\hline & & Mean (kg) & $421 \pm 72.5$ & $381 \pm 28.8$ & $402 \pm 74.0$ & \\
\hline & & Range (kg) & $338-470$ & $348-428$ & $304-488$ & \\
\hline & Afrikaner & $\mathrm{n}$ & & 9 & & \\
\hline & & Mean (kg) & & $332 \pm 35.9$ & & \\
\hline & & Range (kg) & & $286-374$ & & \\
\hline & Nguni & $\mathrm{n}$ & & 8 & 4 & \\
\hline & & Mean (kg) & & $325 \pm 18.4$ & $363 \pm 27.0$ & \\
\hline & & Range (kg) & & $304-354$ & $340-396$ & \\
\hline \multirow[t]{12}{*}{30} & Simmentaler cross & $\mathrm{n}$ & 3 & 12 & 1 & \\
\hline & & Mean & $465 \pm 41.2$ & $559 \pm 35.6$ & 586 & \\
\hline & & Min & $420-501$ & $486-620$ & & \\
\hline & Bonsmara cross & $\mathrm{n}$ & & & 13 & 4 \\
\hline & & Mean (kg) & & & $527 \pm 49.9$ & $553 \pm 18.1$ \\
\hline & & Range (kg) & & & $440-600$ & $530-570$ \\
\hline & Afrikaner & $n$ & & 2 & 7 & 4 \\
\hline & & Mean (kg) & & $428 \pm 39.6$ & $435 \pm 29.5$ & $420 \pm 21.6$ \\
\hline & & Range (kg) & & $400-456$ & $400-462$ & $390-440$ \\
\hline & Nguni & $\mathrm{n}$ & & 1 & 16 & \\
\hline & & Mean (kg) & & 420 & $416 \pm 30.2$ & \\
\hline & & Range (kg) & & & $350-472$ & \\
\hline
\end{tabular}

A clear relationship between live weight and fat classification code cannot be identified (Table 5). In most cases, factors such as normal genetic variation (Sullivan et al., 1999) and the low/medium quality of the available feed (natural pasture) make it difficult to establish significant relationships concerning growth and weight parameters. The large variation in live weight within each weight group combined with the few animals in some weight-fat class groups support the above explanation. Due to the inability to identify a significant relationship between live weight and fat classification code (Table 5), it was not possible to predict the actual market readiness of these steers at a particular age from the live weight at that age. Other measurements such as the visual assessment of slaughter readiness will have to be used to identify animals that are finished and ready to be marketed. At 18 months of age only one NG steer had one permanent 
incisor (Table 6). All the other animals had only temporary teeth. At 24 months of age 92.3\% SX, 42.1\% BX, 55.6\% AF and 58.3\% NG steers still had no permanent incisors. The rest of the steers had either one or two permanent incisors and were classified AB. It is evident that even at this young age many steers had already started to become physiologically mature. At 30 months of age only $7.7 \%$ of AF steers had no permanent incisor. Most steers already had two permanent incisors (SX 62.5\%, BX 76.5\%, AF 84.6\%, and NG 76.5\%), while a meaningful proportion was classified in the B age class for having either three or four permanent incisors. The frequency distributions for number of visible permanent incisors of the different maturity types were similar between breeds at 18 months of age. At 24 months of age fewer $(\mathrm{P}<0.05) \mathrm{SX}$ steers had permanent incisors than the BX steers, while at 30 months of age more $(\mathrm{P}<0.05) \mathrm{SX}$ steers had three or four permanent incisors than the AF steers.

Table 6 The frequency distribution of Simmentaler cross, Bonsmara cross, Afrikaner and Nguni steers having 0 to 4 permanent incisors at 18, 24 and 30 months of age

\begin{tabular}{|c|c|c|c|c|c|c|}
\hline \multirow{2}{*}{$\begin{array}{c}\text { Age at } \\
\text { slaughter } \\
\text { (months) }\end{array}$} & \multirow[t]{2}{*}{ Frame size type } & \multicolumn{5}{|c|}{ Number of permanent incisors } \\
\hline & & 0 & 1 & 2 & 3 & 4 \\
\hline \multirow[t]{5}{*}{18} & Simmentaler cross & 9 & & & & \\
\hline & Bonsmara cross & 9 & & & & \\
\hline & Afrikaner & 8 & & & & \\
\hline & Nguni & 9 & 1 & & & \\
\hline & Total $^{\mathrm{a}}$ & 35 & 1 & & & \\
\hline \multirow[t]{5}{*}{24} & Simmentaler cross ${ }^{\mathrm{d}}$ & 12 & & 1 & & \\
\hline & Bonsmara cross $^{\mathrm{e}}$ & 7 & 1 & 9 & & \\
\hline & Afrikaner ${ }^{\mathrm{de}}$ & 5 & 3 & 1 & & \\
\hline & Nguni $^{\text {de }}$ & 7 & 1 & 4 & & \\
\hline & Total $^{\mathrm{b}}$ & 31 & 5 & 15 & & \\
\hline \multirow[t]{5}{*}{30} & Simmentaler cross ${ }^{\mathrm{d}}$ & & & 10 & 1 & 5 \\
\hline & Bonsmara cross $^{\text {de }}$ & & & 13 & 2 & 2 \\
\hline & Afrikaner ${ }^{\mathrm{e}}$ & 1 & & 11 & 1 & \\
\hline & Ngunid $^{\text {de }}$ & & & 13 & & 4 \\
\hline & Total $^{\mathrm{C}}$ & 1 & & 47 & 4 & 11 \\
\hline \multirow[t]{5}{*}{ Total } & Simmentaler cross & 21 & & 11 & 1 & 5 \\
\hline & Bonsmara cross & 16 & 1 & 22 & 2 & 2 \\
\hline & Afrikaner & 14 & 3 & 12 & 1 & \\
\hline & Nguni & 16 & 2 & 17 & & 4 \\
\hline & Total & 67 & 6 & 62 & 4 & 11 \\
\hline
\end{tabular}

At 30 months of age $23.8 \%$ of all steers had three or four visible incisors. Even if this proportion is a true reflection of the population teething rate, the magnitude of the weight gain achieved from 24 months of age to 30 months of age, coupled with the inexpensive food source utilized, should more than compensate for losses due to the lower age classification of these carcasses.

\section{Conclusions}

In order to take maximum advantage of rapid weight gains, marketing steers from natural pastures in arid regions should be done at the end of the wet summer season (18 and 30 months of age in the case of this study). Steers received higher fat classification codes at the end of the wet season than at the end of the dry season and were the highest at 30 months of age. If marketing steers before the age of 30 months is considered, animals should be fed in a feedlot or supplemented on the natural pasture.

Bonsmara crossbreds, AF and NG steers received better fat classification codes than SX steers at all slaughtering ages. At 30 months of age SX steers still received mainly a 1 fat classification code. Thus, it 
seems that large framed breeds (mean cow weight $>500 \mathrm{~kg}$ ) may need supplementation on natural pastures or be finished off in a feedlot to achieve a 2 fat classification code. None the less, the finishing of large framed breeds from natural pastures is not recommended.

Although 23.8\% of all steers had more than two visible permanent incisors at 30 months of age, most steers were classified as the AB age class. Marketing at a marginal earlier age (27 months) may provide an opportunity to utilise the period of high growth and reduce the number of animals being classified in the $\mathrm{B}$ age class.

\section{References}

Acocks, J.P.H., 1988. Veld types of South Africa. Memoirs of the Botanical Survey of South Africa. 57 p.

Bennett, L.L., Hammond, A.C., Williams, M.J., Kunkle, W.E., Johnson, D.D., Preston, R.L. \& Miller, M.F., 1995. Performance, carcass yield and carcass quality characteristics of steers finished on Rhizoma peanut (Arachis glabrata) - Tropical grass pasture or concentrate. J. Anim. Sci. 73, 1881-1887.

Bidner, T.D., Schupp, A.R., Mohamad, A.B., Rumore, N.C., Montgomery, R.E., Bagley, C.P. \& Mcmillin, K.W., 1986. Acceptability of beef from Angus-Hereford or Angus-Hereford-Brahman steers finished on all-forage or a high-energy diet. J. Anim. Sci. 62, 381-387.

Brand, A.A., Cloete, S.W.P. \& Coetzee, J., 1989. Urea ammoniation of wheat, oat and barley straw and oat hay. 1. A laboratory investigation into the effect of urea and moisture level and treatment period on chemical composition and in vitro digestibility. S. Afr. J. Anim. Sci. 19, 4-10.

Camfield, P.K., Brown, A.H., Johnson, Z.B., Lewis, P.K. \& Brown, C.J., 1994. Effect of growth type on weight-age and carcass data of beef developed on pasture and in the feedlot. J. Anim. Sci. 72 (Suppl. 2), 26.

Camfield, P.K., Brown, A.H., Lewis, P.K., Rakes, L.Y. \& Johnson, Z.B., 1997. Effects of frame size and time-on-feed on carcass characteristics, sensory attributes and fatty acid profiles of steers. J. Anim. Sci. 75, 1837-1844.

Camfield, P.K., Brown, A.H., Johnson, Z.B., Brown, C.J., Lewis, P.K. \& Rakes, L.Y., 1999. Effects of growth type on carcass traits of pasture- or feedlot-developed steers. J. Anim. Sci. 77, 2437-2443.

Cianzio, D.S., Topel, D.G., Whitehurst, G.B., Beitz, D.C. \& Self, H.L., 1982. Adipose tissue growth in cattle representing two frame sizes: Distribution among depots. J. Anim. Sci. 55, 305-312.

Coetzee, J.J., 1971. Die landbou potensiaal van die Noordwes-Transvaalse Soetbosveld. D. Agric. (Inst. Agrar) Thesis, Universiteit van Pretoria. 245 p.

Crouse, J.D., Ferrel, C.L. \& Cundiff, L.V., 1985. Effects of sex condition, genotype and diet on bovine growth and carcass characteristics. J. Anim. Sci. 60, 1219-1227.

Dekker, B., Kirkman, K.P. \& Du Plessis, S.I., 2001. Use of the dry-weight-rank method of botanical analysis in semi-arid savanna communities. Afr. J. Range For. Sci. 2001, 63-68.

Dikeman, M.E., Dayton, A.D., Hunt, M.C., Kastner, C.L., Axe, J.B. \& Ilg, H.J., 1985a. Conventional versus accelerated beef production with carcass electrical stimulation. J. Anim. Sci. 61, 573-583.

Dikeman, M.E., Nagele, K.N., Myers, S.M., Schalles, R.R., Kropf, D.H., Kastner, C.L. \& Russo, F.A., 1985b. Accelerated versus conventional beef production and processing. J. Anim. Sci. 61, 137-150.

Fortin, A., Reid, T.J., Maiga, A.M., Sim, D.W. \& Wellington, G.H., 1981. Effect of energy intake level and influence of breed and sex on the physical composition of the carcass of cattle. J. Anim. Sci. 51, 331339.

Gertenbach, W.D. \& Henning, P.W.Van H., 1995a Energy supplementation of yearling steers at different stocking rates on Nile grass pasture. S. Afr. J. Anim. Sci. 25, 105-108.

Gertenbach, W.D. \& Henning, P.W.Van H., 1995b. Performance of beef steers on Smuts finger grass and Nile grass pasture in Northern Natal. 2. Feedlot performance following summer grazing. S. Afr. J. Anim. Sci. 25, 101-104.

Gertenbach, W.D., Henning, P.W.Van H. \& Van Schalkwyk, A.P., 1995. Performance of beef steers on Smuts finger grass and Nile grass pasture in Northern Natal. 1. Effect of over wintering level and summer stocking rate. S. Afr. J. Anim. Sci. 25, 95-100.

Government Notice No. R. 1748, 26 June 1992. Regulation Gazette No. 4890, Government Gazette No. 14060, Vol. 3245, p. 8.

Harris, J.J., Lunt, D.K., Smith, S.B., Mies, W.L., Hale, D.S., Koohmaraie, M. \& Savell, J.W., 1997. Live animal performance, carcass traits and meat palatability of calf- and yearling-fed cloned steers. J. Anim. Sci. 75, 986-992. 
Koch, R.M., Dikeman, M.E., Allen, D.M., May, M., Crouse, J.D. \& Campion, D.R., 1976. Characterization of biological types of cattle. III. Carcass composition, quality and palatability. J. Anim. Sci. 43, 48-62.

Koch, R.M., Dikeman, M.E., Lipsey, R.J., Allen, D.M. \& Crouse, J.D., 1979. Characterization of biological types of cattle - Cycle II: III. Carcass composition, quality and palatability. J. Anim. Sci. 49, 448-460.

Le Roux, C.J.G., Swart, J.S., Oosthuysen, E., Trethewey, C., Pittaway, C. \& Daines, T., 1999a. Prediction of cattle performance on Coastcross 2 at different fertilizer and stocking rates. S. Afr. J. Anim. Sci. 29, 64-68.

Le Roux, C.J.G., Swart, J.S., Oosthuysen, E., Trethewey, C., Pittaway, C. \& Daines, T., 1999b. Factors affecting cattle performance on Coastcross 2 at different stocking and fertilizer rates. S. Afr. J. Anim. Sci. 29, 69-73.

May, S.G., Dolezal, H.G., Gill, D.R., Ray, F.K. \& Buchanan, D.S., 1992. Effects of days fed, carcass grade traits, and subcutaneous fat removal on post mortem muscle characteristics and beef palatability. J. Anim. Sci. 70, 444-453.

Meaker, H.J. \& Barnard, J.C., 1988. Beef steers implanted with short, medium, and long-acting anabolic compounds grazing natural pastures and finished in feedlot. S. Afr. J. Anim. Sci. 18, 68-71.

Meissner, H.H., Hofmeyr, H.S., Van Rensburg, W.J.J. \& Pienaar, J.P., 1983. Classification of livestock for realistic prediction of substitution values in terms of a biologically defined Large Stock Unit. Technical Communication No. 175, Department of Agriculture, Republic of South Africa.

Moody, W.G., Little, J.E., Thrift, F.A., Cundiff, L.V. \& Kemp, J.D., 1970. Influence of length of feeding a high roughage ration on quantative and qualitative characteristics of beef. J. Anim. Sci. 31, 866-873.

O'Mary, C.C., Martin, E.L. \& Anderson, D.C., 1979. Production and carcass characteristics of Angus and Charolais x Angus steers. J. Anim. Sci. 48, 239-245.

Pringle, T.D., Williams, S.E., Lamb, B.S., Johnson, D.D. \& West, R.L., 1997. Carcass characteristics, the calpain proteinase system, and aged tenderness of Angus and Brahman crossbred steers. J. Anim. Sci. 75, 2955-2961.

Prior, R.L., Kohlmeier, R.H., Cundiff, L.V., Dikeman, M.E. \& Crouse, J.D., 1977. Influence of dietary energy and protein on growth and carcass composition in different biological types of cattle. J. Anim. Sci. 45, 132-146.

Relling, E.A., Van Niekerk, W.A., Coertze, R.J. \& Rethman, N.F.G., 2001. An evaluation of Panicum maximum cv. Gatton: 2. The influence of stage of maturity on diet selection, intake and rumen fermentation in sheep. S. Afr. J. Anim. Sci. 31, 85-91.

Reyneke, J., 1976. Supplementation of energy and/or protein to steers grazing summer veld. S. Afr. J. Anim. Sci. 6, 59-66.

Schaake, S.L., Skelley, G.C., Halpin, E., Grimes, L.W., Brown, R.B., Cross, D.L. \& Thompson, C.E., 1993. Carcass and meat sensory traits of steers finished on fescue and clover, summer forage, or for different periods in drylot. J. Anim. Sci. 71, 3199-3205.

Schroeder, J.W., Cramer, D.A., Bowling, R.A. \& Cook, C.W., 1980. Palatability, shelf life and chemical differences between forage- and grain finished beef. J. Anim. Sci. 50, 852-859.

Scott, J.D., 1947. Veld management in South Africa. Bull. Dept. Agric. S. Afr. No. 28. (cited by Tainton, 1999).

Smith, G.M., Laster, D.B., Cundiff, L.V. \& Gregory, K.E., 1976. Characterization of biological types of cattle. II. Postweaning growth and feed efficiency of steers. J. Anim. Sci. 43, 37-47.

Snyman, L.D. \& Joubert, H.W., 2002. The chemical composition and in vitro dry matter digestibility of untreated and ammoniated crop residues. S. Afr. J. Anim. Sci. 32, 83-87.

SPSS, 2002. SPSS Version 11.5 for Windows. SPSS Inc., USA (www.spss.com).

Strydom, P.E., Naudé, R.T., Smith, M.F., Kotzé, A., Scholtz, M.M. \& Van Wyk, J.B., 2001. Relationships between production traits in subpopulations of Bonsmara and Nguni cattle. S. Afr. J. Anim. Sci. 31, 181-194.

Sullivan, P.G., Wilton, J.W., Miller, S.P. \& Banks, L.R., 1999. Genetic trends and breed overlap derived from multiple-breed genetic evaluations of beef cattle for growth traits. J. Anim. Sci. 77, 2019-2027.

Swanepoel, J., Casey, N.H., De Bruyn, J.F. \& Naudé, R.T., 1990. Meat studies of indigenous South African cattle. I. Growth performance and carcass characteristics of Afrikaner, Nguni and Pedi bulls fed intensively. S. Afr. J. Anim. Sci. 20, 180-187.

Tainton, N.M., 1999. The ecology of the main grazing lands of South Africa. In: Veld management in South Africa. Ed. Tainton, N.M., University of Natal Press. pp. 48. 
Tatum, J.D., Gronewald, K.W., Seideman, S.C. \& Lamm, W.D., 1990. Composition and quality of beef from steers sired by Piedmontese, Gelbvieh and Red Angus bulls. J. Anim. Sci. 68, 1049-1060.

Taute, A., Van Niekerk, W.A., Rethman, N.F.G. \& Coertze, R.J., 2002. An evaluation of nitrogen fertilised Panicum maximum cv. Gatton at different stages of maturity during autumn: 1. Dry matter yield and certain qualitative parameters. S. Afr. J. Anim. Sci. 32, 208-216.

Van der Merwe, H.J., Von la Chevallerie, M. \& Van Scalkwyk, A.P., 1980. Maize meal supplementation to young steers on summer veld and different planes of nutrition during winter. S. Afr. J. Anim. Sci. 10, 189-196.

Wheeler, T.L., Cundiff, L.V., Koch, R.M. \& Crouse, J.D., 1996. Characterization of biological types of cattle (Cycle IV): Carcass traits and longissimus palatability. J. Anim. Sci. 74, 1023-1035.

Young, A.W. \& Kauffman, R.G., 1978. Evaluation of beef from steers fed grain, corn silage or haylage-corn silage diets. J. Anim. Sci. 64, 41-47. 